\title{
Kant and English Nature Poetry
}

\section{Donald G. Marshall}

UNDERLYING THIS PAPER is a methodological issue. I am a student of British poetry, in particular British poetry from Milton in about 1650 to Wordsworth up to about 1830. My study aims to achieve the general intelligibility that arises from connecting particular poems into a historical narrative set within a broad cultural context. To create this simultaneously connective and interpretive narrative, I need a language with some special capacities. It has to bring out issues that are perceptibly important to the particular poems I have chosen to write about. It must be applicable with enough consistency over a historical range of poems to establish a continuity against which changes take on significance. And it must let a reader glimpse a background that gives depth and scope to whatever is at stake in particular poems.

The methodological question is whether I may legitimately draw any or all of that language from Kant. Here are some arguments against doing so.

1. While Kant wrote in this historical period, he did not know the English poetic tradition, and hence, he cannot be responding to its specific concerns. Moreover, the poet I am interested in, Wordsworth, did not read Kant and cannot have been supported by Kant in whatever thinking goes on in his poetry. Using Kant as part of a historical argument will force me to postulate a "Zeitgeist" that will remain obscure and amorphous and will fail to meet the criteria of precision, concreteness, and clear instantiation that govern historical writing.

2. Apart from the historical issue, Kant is a philosopher. Philosophy weighs the truth of ideas by formulating them precisely and examining arguments for and against them. Even when poetry is explicitly a "poetry of ideas," it works by bringing out the potential of ideas to serve as the substance shaped into forms a reader can perceive with satisfaction. If Lucretius's De rerum natura is a brilliant poem - and it is - that counts neither for nor against Epicurean philosophy. If I use Kant's concepts to describe even philosophical poems, I will cancel what is specifically poetical about them. At the same time, I will illegitimately force the poems to answer questions they did not ask. 
3. Moreover, philosophical ideas are legitimate only when they are true. Some would claim that Kant's is an exploded system - a monument in the history of philosophy, no doubt, but quaint in its scholastic air of conceptual rigor and laughable when it takes seriously outmoded views of the world and human being. Historical interpretation must speak a language that, if not undeniably true, must at least seem not obviously false.

It will surprise no one to learn that I am in no position to resolve these doubts. Even so, it seems promising to note the surprising affinities between Kant and some poetry of the period I've mentioned, in this case, Wordsworth's. And so, I am going to plunge ahead with Kant, despite all the scruples I can invent against doing so.

In 1726, a Scots poet by the name of James Thomson, who had moved to London, published a poem called Winter. It was so successful that he was encouraged to revise it and work his poetic way through the rest of the year. In 1730, the first collected edition of The Seasons appeared, and it was revised and reprinted many times down to the author's death in 1746. Thereafter, it remained one of the most widely known and admired.poems in the language well into the nineteenth century, after which time it rapidly fell from favor and is now read by a few specialists only. In 1798, William Wordsworth and Samuel Coleridge published anonymously a volume titled Lyrical Ballads, With a Few Other Poems. The last poem in that collection was by Wordsworth and had the almost parodically long title "Lines composed a few miles above Tintern Abbey, on revisiting the banks of the Wye during a tour. July 13, 1798." Under its more familiar name, "Tintern Abbey," it remains highly esteemed, the one poem which more than any other is the exemplary instance of "English romanticism."

Here are some lines from Thomson's "Spring":

Hail, Source of Being! Universal Soul Of heaven and earth! Essential Presence, hail!

To thee I bend the knee; to thee my thoughts

Continual climb, who with a master-hand

Hast the great whole into perfection touched.

By thee the various vegetative tribes,

Wrapt in a filmy net and clad with leaves,

Draw the live ether and imbibe the dew.

By thee disposed into congenial soils, 
Stands each attractive plant, and sucks, and swells

The juicy tide, a twining mass of tubes.

At thy command the vernal sun awakes

The torpid sap, detruded to the root

By wintry winds, that now in fluent dance

And lively fermentation mounting spreads

All this innumerous-coloured scene of things.

This is not Thomson's poetry at its best, by any means. But leaving that issue aside, here are some lines from "Tintern Abbey." Wordsworth has been tracing the stages of his mental and moral development and weighing what he has lost, what he has gained, and what has continued undiminished:

And I have felt

A presence that disturbs me with the joy

Of elevated thoughts; a sense sublime

Of something far more deeply interfused, Whose dwelling is the light of setting suns, And the round ocean and the living air, And the blue sky, and in the mind of man:

A motion and a spirit, that impels

All thinking things, all objects of all thought, And rolls through all things.

Both these poets speak of a "presence," but its manifestation is evidently very different. Thomson's presence is "essential," grasped intellectually in each specific natural being through an analysis of its functional coherence, an analysis conducted in emphatically scientific diction. That presence is figured as an artist or artisan, whose attributes are inferred from the order we find in the Book of Nature. Wordsworth's presence is grasped through feeling and sensing. Its lack of specification is compensated by its omnipresence, reinforced by cumulative rhythms that delight in enjambment as they also roll over the boundaries between thinking, feeling, and sensing, between the mind and its objects, between the animate and the inanimate, and give a specious feeling of concreteness to the climactic phrase "rolls through all things." 
A historical discourse in which both these poems figure will evidently need the narrative device of peripety or significant change. Change in what? Change in the content given to the "presence" manifest in nature.

Thomson plainly thinks the evidence of order in nature points to an intelligent artificer. Natural objects exhibit design; design argues purpose; from purpose we infer an agent. Q.E.D. This line of thought-the famous "argument from design"-pervades English religious apologetics in the early eighteenth century. It has been argued that the intellectual and physical battles over religion in the sixteenth and seventeenth centuries left the English wary of dogmatic systems and of claims to biblical, that is, revealed authority. The scientific study of nature, in contrast, was democratically available to anyone with senses and the power to reason. The strategy was to grow specifically religious ideas and feelings on this admittedly thin new soil. The argument from design projected a sketchy "presence," and the language used to describe nature created an intellectually and emotionally complex, but richly specific response to that presence.

Philosophically, the argument from design was demolished by Hume in the Dialogues Concerning Natural Religion (completed about 1751, but prudently withheld from publication until 1779 , three years after his death). The associated response was destroyed by a reassertion of biblical authority and an insistence on a personal relation to God and His Son. One can speculate that those who thought in terms of this debate could not avoid feeling a gap between a scientific conception of the sensory world and the moral and spiritual effect they demanded of religion.

Kant's central aim in the Critique of Judgment is exactly to adjust the relation of these two realms or perhaps sides of human experience. Kant evidently believes that that adjustment requires a second, namely, in the relation between two modes of our experiencing the world-the mode in which we perceive art and the mode in which we perceive nature. In Kant's Life and Thought (which I follow closely here), Ernst Cassirer stresses that what drives Kant's inquiry is philosophical. He is not responding directly to the problem of teleology as he found it formulated in his cultural milieu, but is following out his own reflections on the concept of the a priori. In his Critique of Pure Reason, he analyzed the faculty of knowledge, which takes its coherence from conceptual laws; in his Critique of Practical Reason, he analyzed the faculty of desire, which takes its coherence from moral purposes. Now he discovers a third and co-equal capacity of mind, the feeling 
of pleasure and displeasure. Just as he found an a priori concept underlying each of the other two faculties, he finds here an a priori concept that originates solely in what he calls "reflective judgments."

When we know something, we grasp its unity according to universal laws given by the understanding, laws which are prescribed to nature as a condition perceptual objects must meet in order to be intelligible to us at all. By contrast, reflective judgment is subjective. It grasps an object's unity by invoking a law judgment gives unto itself, namely, to think of an object as if it were brought about by design. In Kant's language, if the concept of an object also functions as the ground for the object's coming into being, then that concept is called the object's "purpose" (20). Where a thing seems to cooperate in making the concept of purpose applicable in judging it, Kant says its form is "purposive." Beautiful nature and works of fine art are instances of this active co-operation, because in the act of perceiving them, our own mental powers are brought into so harmonious a coherence that we cannot help thinking that such works were brought into being precisely to occasion that harmony.

As Cassirer argues, the strength of Kant's analysis is its power to illuminate various experiences we possess. One of these experiences is our perception of art. Art brings into existence objects whose presentation to our mind exhibits some unity of design. We grasp this unity not through our faculty of knowledge, but through our capacity of feeling, that is through our ability to experience pleasure and displeasure. The pleasure involved in art is detached from whatever specific utility the object may have for us and registers simply as the internal harmony that perceiving the artwork creates in us. For Kant the feeling of pleasure and displeasure provides us with a direct apprehension of our individual, mental life. Artworks give us no scientific knowledge of things and provide neither moral instruction nor the means of meeting moral demands. But when we perceive a work of art, in our response to it and there alone we feel our life as such.

In eighteenth-century philosophy and poetry, the response to nature regularly leads to the assertion that a designing intelligence lies behind the scene. Kant's dismissal of such thinking, however, leads to a deepened understanding of teleology. No longer does the perception of design lead to an argument for a separate artificer. Much less is that artificer confined to human ways of making - as in the unexamined anthropomorphism that was the secret ground of the argument for design. But neither is the concept of 
purpose a mere subjective imposition. What the power of reflective judgment manifests is a legitimate capacity to intuit a whole in an experience that, Cassirer says, despite its wholeness does not go beyond our finite, discursive nature. This capacity, Cassirer goes on, yields a new conception both of the self and of nature. When we think of an artwork or a beautiful object of nature, we cannot treat these things as something we know objectively and conceptually. We cannot use it to preempt the labor of finding out the specific laws of nature, nor does it enable us to spell out rules an artwork must obey to be beautiful. We feel it, and we cannot help but feel it, yet we do not explain it. We thus bump up against the boundaries of our human capacities. Through critical reflection we locate those boundaries; we find what we are.

In his reflections on life seen as a whole, Kant adumbrates something further. Like the temporal arts, like music or narrative, the course of individual life and the course of life in its totality forms a whole we feel but cannot specify conceptually. It has a coherence that does not belong to laws of nature nor to a free human will fixed on a moral purpose. Feeling this sort of wholeness enhances our mind's power to encompass the most variegated experiences while maintaining the freedom of our perceiving minds.

I am aware that this glimpse of Kant, through the eyes of Cassirer, is abstract and obscure. Nevertheless, it was exactly these abstractions which Goethe and Schiller said expressed their deepest intuitions about the poetry they wished to write. Like Kant, Wordsworth is notorious for the abstraction and elusiveness of his diction. There is an uncanny fit between the experience Wordsworth is describing and the experience of thinking which Kant analyzes. It is the grasp of his own life which provides the poet with the resources he needs to experience the whole of the natural world as an infinity correlated with the unfolding whole of his own being. Thus, reading Wordsworth through Kant, we can see Wordsworth's poetry as grasping a "presence" in nature in a manner that neither misconceives it as objectively known fact nor shrinks it to mere subjective wish-fulfillment. 